\title{
Review
}

\section{Constituting Freedom: Machiavelli and Florence}

Fabio Raimondi translated by Matthew Armistead

Oxford University Press, Oxford, 2018, xiii + 163pp.,

ISBN: 9780198815457

Original: L'ordinamento della libertà. Machiavelli e Firenze

(Verona: ombre corte, 2013)

Contemporary Political Theory (2020) 19, S112-S115. https://doi.org/10.1057/s41296018-00300-0; published online 2 January 2019

In 1494, following the invasion of Italy by Charles VIII of France, the Medici regime in Florence collapsed. After 60 years of Medici dominance, the Florentines were faced with the challenge of how to reconstitute their political order. Amidst multiple constitutional proposals that were formulated in the ensuing months, the Florentines eventually established the Great Council [Consiglio maggiore], which became the most important constitutional innovation of the republic that lasted from 1494 to 1512 . With about 3000 members and endowed with real authority over important policy domains, the Great Council was the broadest representative institution that ever governed the city. While membership did not extend to workers or women, the Great Council was a radical and revolutionary departure from the oligarchy that had ruled Florence for the previous century. It was this republic that Machiavelli served as Secretary from 1498 to 1512, when the Medici returned to power.

While Machiavelli is typically regarded as having been a loyal republican during his time in office, he is sometimes seen as having retreated from the early commitments to a democratic republic, either for strategic reasons (because he sought employment from the Medici) or because of his supposed disillusionment with the broad-based republic and a late conservative turn in favor of an oligarchic regime of the Venetian type.

Raimondi's short book offers a strong critique and rejoinder of such views, insisting that Machiavelli was 'always a republican' (p. 2) and that his central and abiding theoretical interest, even in his late work, was focused on how to re-order Florence as a broad-based republic (p. 127). Raimondi's core argument is that Machiavelli, in his late work and especially in two short pieces written between 1520 and 1522 (Discourse on Remodeling the Government of Florence and Minuta di provvisione per la Riforma dello Stato di Firenze) remained committed not only

(c) 2019 Springer Nature Limited. 1470-8914 Contemporary Political Theory Vol. 19, S2, S112-S115 
to republican principles, but also to the inclusive representative institutions of which the Great Council is the foremost example. This is a welcome contribution to current debates for two reasons: first, it valorizes a set of texts that are all-too-often ignored, especially in the orbit of anglophone political theory, and second, it challenges the currently dominant reading of these texts as evidence for Machiavelli's late conservatism.

Following his removal from office in the wake of the Medici restoration, Machiavelli began to consider a key politico-theoretical problem that had preoccupied him both in The Prince and the Discourses on Livy: how can a state be re-ordered under conditions of corruption? How can a city that has become servile - in Florence's case, to the Medici - be reinvented as a free republic? Raimondi seeks to show how this pivotal problem that animates both The Prince and the Discourses remains fundamental in the late work: how to order, in a corrupt city, a free and civil way of life [vivere libero e civile].

To make the case, Raimondi first lays out the conceptual problem: how can a city that is corrupt, i.e., one that lacks good laws, orders, and customs, be reformed? The answer, suggested by The Prince and a key section of the Discourses (1.16-18), is that such a city may only be reformable by an individual who suspends the republican order and turns the city temporarily into a principality. The problem with this course of action, Machiavelli noted, is that 'reordering a city for a political way of life presupposes a good man, and becoming prince of a republic by violence presupposes a bad man' (Discourses, 1.18). Therefore, the search for a prospective prince who is willing to topple an existing regime only to install republican institutions is unlikely to be successful.

A more plausible scenario is that such a city becomes a principality. Yet in this case, the city faces the central problem that principalities encounter, namely how to ensure stability over time. As The Prince emphasizes, the main challenge for principalities is succession. Unlike republics, which have institutions in place that ensure durability of the political order over time, for new principalities, every succession marks a political crisis.

Fortunately, Florence was not an entirely corrupt republic, and hence its outlook was not as bleak as these reflections suggest. Indeed, Florence's peculiarity, as Machiavelli pointed out in the Discourse on Remodeling the Government of Florence, was that it always sported an ambiguous political system: neither entirely republican nor entirely princely. According to Raimondi, Machiavelli viewed this 'hybrid and unstable form of government' (p. 39) to be both Florence's Achilles heel and its most auspicious virtue. Florence's political instability manifested itself in civil conflict and discord, what Machiavelli called 'tumults.' And unlike most of his contemporaries, Machiavelli famously regarded tumults as a political virtue rather than as a liability.

(C) 2019 Springer Nature Limited. 1470-8914 Contemporary Political Theory Vol. 19, S2, S112-S115 S113 
By highlighting the role of tumults as 'engine of innovation and manifestation of freedom' (p. 43) and as cause for 'the greatest possible equality in a republic' (p. 49), Raimondi aligns himself with a growing literature that emphasizes the importance of social and political conflict for Machiavelli's thinking. This theoretical orientation emerges clearly from Raimondi's gloss of Machiavelli's conception of freedom: 'an unbalanced equilibrium that is asymmetrical, unstable, and always teetering on the brink of chaos, like an acrobat swaying as he walks on the high wire' (p. 50).

Yet while tumults can serve as engines of freedom, they are insufficient to organize a lasting free way of life. Machiavellian political freedom, on Raimondi's interpretation, is not reducible to the struggle against domination; it demands orders. Hence, Raimondi focuses on institutions and offers an interpretation of Machiavelli's late work as a constitutional theorist. That Machiavelli was interested in institutional innovation is uncontroversial. Yet Raimondi's emphasis on Machiavelli as a constitutional theorist, who treats freedom not simply as nondomination but as requiring concrete impersonal orders, such as offices, magistracies, and collective bodies (pp. 72, 128) offers an important correction to democratic interpretations that advance abstractly philosophical accounts of Machiavellian freedom.

Because Machiavelli's constitutional writings of 1520-1522 propose three levels of representative institutions (for elites, the middle, and the many), they are frequently regarded as an effort at balancing power. On this reading, the different levels of institutions function as countervailing forces that yield an Aristotelian equilibrium. It is partly on these grounds that interpreters have advanced the thesis that Machiavelli's late work exhibits a turn toward the oligarchic Venetian model. Raimondi strongly rejects this view and insists that the constitutional proposals are sui generis, because they seek not equilibrium between competing forces but fusion (p. 131). According to Raimondi, the objective of the constitutional proposals is ultimately a 'merger of the three levels of the state' ( $p$. 117) that is distinct from and incompatible with the Aristotelian and Venetian models. Thus, Raimondi categorizes Machiavelli's constitutional proposals as 'dynamic' and 'open' (p. 135), animated by internal movement rather than by a search for equilibrium.

The argument that Machiavelli's late work articulates a proposal for an open constitution that is permanently in motion is innovative and striking. Yet, unfortunately, this line of reasoning is sketched out rather hastily in the final pages of the book and does not receive the full and robust elaboration it needs and merits. The nature of this constitutional mixture or fusion is left vague and the theoretical and political questions it raises unexplored. This is unfortunate, because a cogent refutation of the Aristotelian/Venetian reading of these texts would go a long way to buttress Raimondi's rejection of the currently dominant interpretation of Machiavelli's late writings. Despite these qualms, Constituting Freedom is a bold 
and refreshing contribution to the democratic and radical currents of Machiavelli studies and opens up important new terrain.

Yves Winter

McGill University, Montreal, QC H3A 0G4, Canada yves.winter@mcgill.ca

Publisher's Note Springer Nature remains neutral with regard to jurisdictional claims in published maps and institutional affiliations. 